Al-Khwarizmi: Jurnal Pendidikan Matematika dan Ilmu Pengetahuan Alam

Oktober-2019, Vol.7, No.2, hal.97-112

$\operatorname{ISSN}(P):$ 2337-7666; ISSN(E):2541-6499

https://ejournal.iainpalopo.ac.id/index.php/al-khwarizmi

DOI: http://dx.doi.org/10.24256/ipmipa.v7i2.799

\title{
Regresi Spline Polynomial Truncated Biprediktor untuk Identifikasi Perubahan Jumlah Trombosit Pasien Demam Berdarah Dengue
}

\author{
Anna Islamiyanti \\ Departemen Statistika, Fakultas Matematika dan Ilmu Pengetahuan Alam, \\ Universitas Hasanuddin \\ Jl. Perintis Kemerdekaan KM.10 Tamalanrea, Makassar, Indonesia \\ Email:annaislamiyati@unhas.ac.id
}

\section{Article History:}

Received: 27-08-2019; Received in Revised: 19-09-2019; Accepted: 21-10-2019

\begin{abstract}
This paper is a longitudinal study using a nonparametric regression model to identify changes in platelet count from dengue fever. Changes in platelet counts were analyzed based on treatment time and hematocrit count factors. The estimator method proposed is spline polynomial truncated bipredictor. Based on the results of the simultaneous model estimation, we obtained GCV $=714.72$ and $R 2=95.9 \%$, it means the model is feasible to explain and identify changes in platelet count based on the time of treatment and the number of hematocrit from DBD patients. Based on the data, there are four patterns of platelet change based on time of treatment and three patterns of platelet change based on hematocrit that are different from each other.
\end{abstract}

Keywords: DBD; Hematocrit; Longitudinal; Spline Bipredictor; Platelet.

\begin{abstract}
Abstrak
Paper ini merupakan studi longitudinal dengan menggunakan model regresi nonparametrik untuk mengidentifikasi perubahan jumlah trombosit demam berdarah. Perubahan jumlah trombosit dianalisis berdasarkan faktor waktu perawatan dan jumlah hematokrit. Metode estimator yang diusulkan adalah spline polynomial truncated bi prediktor. Berdasarkan hasil taksiran model simultan diperoleh $G C V=714,72$ dan $R^{2}=95,9 \%$, artinya model layak untuk menjelaskan dan mengidentifikasi perubahan jumlah trombosit berdasarkan waktu perawatan dan jumlah hematokrit pasien DBD. Berdasarkan data, terdapat empat pola perubahan trombosit berdasarkan waktu perawatan dan tiga pola perubahan trombosit berdasarkan hematokrit yang berbeda satu sama lain.
\end{abstract}

Kata Kunci: DBD; Hematokrit; Longitudinal; Spline Biprediktor; Trombosit. 


\section{Pendahuluan}

Penyakit Demam Berdarah Dengue (DBD) adalah salah satu penyakit menular yang dapat menimbulkan kematian dalam waktu singkat dan sering menimbulkan wabah pada suatu wilayah. Hal ini disebabkan karena penyakit DBD memiliki penyebaran sangat cepat, tetapi belum ditemukan obat untuk penyembuhan, juga belum ditemukan vaksin untuk pencegahan. DBD menjadi penyakit infeksi berbasis lingkungan, penyebab utama morbiditas dan mortalitas pada masyarakat ${ }^{1}$.

Seluruh wilayah Indonesia mempunyai resiko untuk terjangkit penyakit DBD karena virus penyebabnya bersumber dari nyamuk, tersebar luas baik di rumah maupun tempat-tempat umum, kecuali yang ketinggian lebih dari 1.000 meter di atas permukaan laut. DBD adalah suatu penyakit yang disebabkan oleh infeksi virus Dengue, dan ditularkan melalui gigitan nyamuk Aedes Aegypti betina, dan beberapa spesies Aedes lainnya ${ }^{2}$. Serangan virus terjadi pada sel trombosit sehingga indikator utama seseorang terkena DBD dalam pengujian medis adalah pengukuran sel trombosit ${ }^{3}$.

Beberapa penelitian tentang DBD menyebutkan bahwa penurunan jumlah trombosit pada pasien dapat menunjukkan indikasi terkena DBD. Namun selain jumlah trombosit, diperlukan pemeriksaan medis lain diantaranya pemeriksaan kandungan hematokrit karena keduanya merupakan sel darah. Berdasarkan analisis survival menunjukkan bahwa tingkat kesembuhan seseorang berhubungan signifikan dengan hematokrit, trombosit, dan interaksi antara hematokrit dan trombosit ${ }^{4}$. Selain itu, pengukuran data medis bagi penderita DBD sangat bervariasi sehingga analisis DBD perlu diperhatikan pada setiap hari perawatan. Hal ini disebabkan karena kemungkinan dalam setiap waktu terdapat perubahan yang terjadi dan memerlukan tindakan medis pada waktu tersebut. Biasanya, seorang dokter membangun pengetahuannya terkait dengan gejala

${ }^{1}$ Reinhard Y. Lontoh, A J M Rattu, and Wulan P. J. Kaunang, "Hubungan Antara

2 Kementerian Kesehatan Republik Indonesia, "Demam Berdarah Biasanya Mulai Meningkat Di Januari," January 8, 2015, http://www.depkes.go.id/ article/print/15011700003.

3 Acivrida Mega Charisma, "Gambaran Hasil Pemeriksaan Jumlah Trombosit Dan Nilai Hematokrit Pada Pasien Demam Berdarah Dengue (DBD) Di RSU Anwar Medika Periode Februari-Desember 2016," Journal of Pharmacy and Science 2, no. 2 (July 7, 2017): 15-19.

4 Shofa F. Nisai and I. Nyoman Budiantara, "Analisis Survival dengan Pendekatan Multivariate Adaptive Regression Splines pada Kasus Demam Berdarah Dengue (DBD)," Jurnal Sains dan Seni ITS 1, no. 1 (September 11, 2012): D318-D323-D323, https://doi.org/10.12962/j23373520.v1i1.2165. 
pasien dan tanggapan terhadap obat dari waktu ke waktu berdasarkan pengamatan 5 .

Salah satu studi yang mempertimbangkan pengaruh waktu terhadap respon adalah studi longitudinal. Data longitudinal terdiri dari beberapa subyek yang diukur berulang berdasarkan waktu. Jenis data longitudinal sudah banyak ditemukan pada data riil termasuk bidang kesehatan karena pemeriksaan medis yang berulang pada setiap pasien ${ }^{6}$. Oleh sebab itu, paper ini menggunakan studi data longitudinal dalam mengidentifikasi pola perubahan jumlah trombosit pasien DBD.

Penelitian yang telah dilakukan Nisa dan Budiantara (2012) menunjukkan bahwa pola perubahan trombosit pasien selama perawatan cenderung tidak mengikuti pola parametrik ${ }^{7}$. Suatu data yang tidak dapat dipolakan dengan regresi parametrik dapat diestimasi dengan regresi nonparametrik ${ }^{8}$. Regresi nonparametrik sudah banyak dikembangkan oleh peneliti. Grajeda, Laura, Ivanescu dan Checkley (2016) mengembangkan spline kubik ${ }^{9}$. Chamidah, Budiantara, Sunaryo dan Ismaini (2012) mengembangkan estimator polinomial lokal ${ }^{10}$. Budiantara, Ratnasari, Ratna, dan Zain (2015) mengembangkan kombinasi estimator kernel dengan spline ${ }^{11}$. Islamiyati, Fatmawati dan Chamidah (2018) mengembangkan estimator penalized spline ${ }^{12}$. Selanjutnya, Aydin, Memmedli dan Omay (2013)13; Lestari, Fatmawati dan Budiantara (2018) mengembangkan

${ }^{5}$ Manjeevan Seera et al., "A Hybrid FAM-CART Model and Its Application to Medical Data Classification," Neural Computing and Applications 26, no. 8 (November 1, 2015): 17991811, https://doi.org/10.1007/s00521-015-1852-9.

6 Anna Islamiyati, "Taksiran Kurva Regresi Spline Pada Data Longitudinal Dengan Kuadrat Terkecil," Jurnal Matematika, Statistika Dan Komputasi 11, no. 1 (February 1, 2018): 77-83, https://doi.org/10.20956/jmsk.v11i1.3432.

7 Nisai and Budiantara, "Analisis Survival dengan Pendekatan Multivariate Adaptive Regression Splines pada Kasus Demam Berdarah Dengue (DBD).”

${ }^{8}$ Nur Chamidah and Budi Lestari, "Spline Estimator in Homoscedastic Multiresponse Nonparametric Regression Model in Case of Unbalanced Number of Observations," Far East Journal of Mathematical Sciences (FJMS) 100 (November 3, 2016): 1433-53, https://doi.org/10.17654/MS100091433.

${ }^{9}$ Laura M. Grajeda et al., "Modelling Subject-Specific Childhood Growth Using Linear Mixed-Effect Models with Cubic Regression Splines," Emerging Themes in Epidemiology 13 (January 7, 2016), https://doi.org/10.1186/s12982-015-0038-3.

${ }^{10}$ N. Chamidah et al., "Designing of Child Growth Chart Based on Multi-Response Local Polynomial Modeling," Journal of Mathematics and Statistics 8, no. 3 (2012): 342-347.

${ }^{11}$ I. Nyoman Budiantara et al., "The Combination of Spline and Kernel Estimator for Nonparametric Regression and Its Properties," Applied Mathematical Sciences 9, no. 122 (2015): 6083-6094.

12 A. Islamiyati, Fatmawati, and N. Chamidah, "Estimation of Covariance Matrix on BiResponse Longitudinal Data Analysis with Penalized Spline Regression," Journal of Physics: Conference Series 979 (March 2018): 012093, https://doi.org/10.1088/1742-6596/979/1/012093.

${ }^{13}$ Dursun Aydın, Memmedağa Memmedli, and Rabia Ece Omay, "Smoothing Parameter Selection for Nonparametric Regression Using Smoothing Spline | Aydın | European Journal of Pure and Applied Mathematics," accessed December 7, 2019, https://www.ejpam.com/index.php/ejpam/article/view/1362. 
estimator smoothing spline ${ }^{14}$. Artikel ini mengusulkan penggunaan estimator spline polynomial truncated karena memiliki sifat yang lebih fleksibel dan mudah diinterpretasikan secara visual ${ }^{15}$.

Data yang berbentuk longitudinal telah dianalisis melalui penggunaan spline seperti yang telah dilakukan Islamiyati (2017) ${ }^{16}$. Beberapa jenis data longitudinal pada bidang kesehatan dengan regresi nonparametrik diantaranya data AIDS oleh Liang dan Xiao (2006) ${ }^{17}$, penyakit leukemia oleh Sriliana dan Budiantara (2012) ${ }^{18}$, pertumbuhan bayi di Surabaya oleh Chamidah dan Rifada (2016) ${ }^{19}$, dan data pasien diabetes mellitus type 2 oleh Islamiyati, Fatmawati dan Chamidah (2017) ${ }^{20}$. Akan tetapi, penelitian tersebut hanya mempertimbangkan pengaruh waktu, tanpa melihat pengaruh faktor lain yang mempengaruhi respon. Kajian teoritis mengenai regresi spline polynomial truncated dengan beberapa prediktor telah diteliti pada data cross section diantaranya Sudiarsa, Budiantara, Suhartono dan Purnami $(2015)^{21}$. Regresi spline polynomial truncated adalah model regresi nonparametrik berbentuk polinomial yang mempertimbangkan titik knot sehingga terdapat perubahan pola pada setiap interval. Adapun untuk data longitudinal, Islamiyati, Fatmawati dan Chamidah (2019) menggunakan estimator penalized spline 22 . Oleh sebab itu, penelitian ini mengestimasi

${ }^{14}$ B. Lestari et al., "Estimation of Regression Function in Multi-Response Nonparametric Regression Model Using Smoothing Spline and Kernel Estimators," Journal of Physics: Conference Series 1097 (September 2018): 012091, https://doi.org/10.1088/17426596/1097/1/012091.

${ }^{15}$ Anna Islamiyati, "Spline Polynomial Truncated Dalam Regresi Nonparametrik," Jurnal Matematika, Statistika Dan Komputasi 14, no. 1 (February 11, 2018): 54-60, https://doi.org/10.20956/jmsk.v14i1.3538. Terkecil."'

${ }^{16}$ Islamiyati, "Taksiran Kurva Regresi Spline Pada Data Longitudinal Dengan Kuadrat

${ }^{17}$ Hua Liang and Yuanhui Xiao, "Penalized Splines For Longitudinal Data With An Application In AIDS Studies," Journal of Modern Applied Statistical Methods 5, no. 1 (May 1, 2006), https://doi.org/10.22237/jmasm/1146456660.

${ }^{18}$ Idhia Sriliana and Nyoman Budiantara, "Truncated Spline Regression in Linear Partial Model for Longitudinal Data," 2012.

${ }^{19}$ N. Chamidah and M. Rifada, "Local Linear Estimator in Bi-Response Semiparametric Regression Model for Estimating Median Growth Charts of Children," Far East Journal of Mathematical Sciences 99, no. 8 (2016): 1233.

${ }^{20}$ Anna Islamiyati, Fatmawati, and Nur Chamidah, "Fungsi Goodness of Fit Dalam Kriteria Penalized Spline Pada Estimasi Regresi Nonparametrik Birespon Untuk Data Longitudinal," in Prosiding Seminar Nasional Matematika dan Aplikasinya 2017: Peranan Matematika dan Sistem Informasi di Era Big Data untuk Menunjang Perkembangan Iptek di Indonesia (Surabaya: Departemen Matematika Fakultas Sains dan Teknologi Universitas Airlangga Surabaya, 2017), 216-21, Islamiyati_Statistika_pdf. http://math.fst.unair.ac.id/wp-content/uploads/2017/10/32-Anna-

${ }_{21}$ I. Wayan Sudiarsa et al., "Combined Estimator Fourier Series and Spline Truncated in Multivariable Nonparametric Regression,” Applied Mathematical Sciences 9 (2015): 4997-5010, https://doi.org/10.12988/ams.2015.55394.

22 Anna Islamiyati, Fatmawati, and Nur Chamidah, "Ability of Covariance Matrix in BiResponse Multi-Prredictor Penalized Spline Model Through Longitudinal Data Simulation," preprint (INA-Rxiv, November 6, 2019), https://doi.org/10.31227/osf.io/bjqv4. 
fungsi regresi nonparametrik biprediktor dengan estimator spline polynomial truncated pada data longitudinal. Selanjutnya, metode digunakan untuk memodelkan jumlah trombosit pasien DBD. Model simultan bertujuan untuk mengidentifikasi pola perubahan kandungan trombosit pasien DBD berdasarkan waktu perawatan dan jumlah hematorit.

\section{Metode}

Data yang digunakan dalam paper ini adalah data sekunder dari data rekam medik pasien rawat inap penderita DBD pada tahun 2017 di Rumah Sakit Pendidikan Universitas Hasanuddin Makassar. Pengambilan data ini dibatasi pada pengukuran kadar trombosit dan hematokrit pasien yang diperiksa setiap harinya selama perawatan di rumah sakit. Pasien yang dipilih adalah pasien DBD berumur 0-15 tahun dan menjalani rawat inap selama 11 hari. Variabel dalam penelitian ini menggunakan satu variabel respon dan dua variabel prediktor. Yaitu faktor jumlah trombosit pasien sebagai variabel respon $(y)$, faktor waktu perawatan $\left(x_{1}\right)$ dan faktor jumlah hematokrit $\left(X_{2}\right)$ sebagai variabel prediktor $(x)$.

Data dianalisis dengan model regresi spline polynomial truncated biprediktor. Budiantara, Ratna, Zain, dan Wibowo (2012) telah mengembangkan penggunaan spline ${ }^{23}$. Spline adalah potongan polinomial order $p$, dengan titik bersama dari potongan-potongan tersebut disebut dengan knots. Titik knots merupakan perpaduan dua kurva yang menunjukkan pola perubahan perilaku kurva pada selang yang berbeda. Spline orde $p$ pada setiap subyek ke- $i$ dengan pengukuran ke- $j$, memiliki titik knots pada $k_{i 1}, k_{i 2}, \mathrm{~K}, k_{i m}$ diberikan dalam fungsi $f$ dengan bentuk:

$$
f_{i}\left(t_{i j}\right)=\sum_{s=1}^{p} \beta_{i s} t_{i j}^{s}+\sum_{s=1}^{m} \beta_{i[s+p]}\left(t_{i j}-k_{i s}\right)_{+}^{p}, i=1,2, \ldots r j \quad \ldots n_{i},
$$

dengan $\beta_{i 1}, \mathrm{~K}, \beta_{i[p+j]}$ adalah parameter fungsi spline pada subjek ke- $i$,

$$
\left(t_{i j}-k_{i s}\right)_{+}^{p}=\left\{\begin{array}{cc}
\left(t_{i j}-k_{i s}\right)^{p} & ,\left(t_{i j}-k_{i s}\right) \geq 0 \\
0 & ,\left(t_{i j}-k_{i s}\right)<0
\end{array}\right. \text {. }
$$

Fungsi (1) merupakan fungsi spline polynomial truncated pada data longitudinal dengan 1 prediktor $t$. Jika diberikan suatu basis untuk spline berbentuk $\left\{1, t_{i j}, \ldots, t_{i j}^{p},\left(t_{i j}-k_{i 1}\right)_{+}^{p}, \ldots \ldots,\left(t_{i j}-k_{i m}\right)_{+}^{p}\right\}$, maka $y_{i j}$ dapat dinyatakan sebagai berikut:

$$
y_{i j}=\sum_{s=0}^{p} \beta_{i s} t_{i j}^{s}+\sum_{s=1}^{m} \beta_{i[s+p]}\left(t_{i j}-k_{i s}\right)_{+}^{p}+\varepsilon_{i j},
$$

${ }^{23}$ I. Nyoman Budiantara et al., "Modeling the Percentage of Poor People in Indonesia Using Spline Nonparametric Regression Approach," International Journal of Basic \& Applied Sciences 12 (2012): 119-124. 
dengan $p$ adalah derajat polynomial dan $m$ adalah banyaknya titik knots pada fungsi truncated serta $\varepsilon_{i j}$ adalah residual. Selanjutnya estimasi model diperoleh:

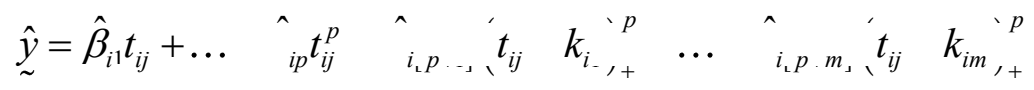

Mengestimasi kurva regresi nonparametrik dengan pendekatan spline polynomial truncated, berarti mencari model spline polynomial truncated optimal berdasarkan titik knots optimal yaitu berapa banyak titik knots dan dimana letak titik-titik knots tersebut. Pemilihan titik-titik knots yang optimal menggunakan metode GCV sebagai berikut:

$$
G C V(k)=\frac{n^{-1}{\underset{\sim}{y}}^{T}\lceil\mathbf{I}-\mathbf{A}(k)\rceil^{T}[\mathbf{I}-\mathbf{A}(k)\rceil \underset{\sim}{y}}{\left(n^{-1} \operatorname{trace}[\mathbf{I}-\mathbf{A}(k)]\right)}
$$

\section{Estimasi Fungsi Spline Polynomial Truncated dengan Bi Prediktor}

Pendekatan spline dengan melibatkan prediktor lebih dari satu telah dikembangkan oleh Islamiyati (2019) melalui estimator penalized spline ${ }^{24}$. Pada artikel ini, digunakan estimator spline polynomial truncated dengn melibatkan dua variabel prediktor $(q=1,2)$ yaitu $x_{1}$ dan $x_{2}$, dapat dituliskan sebagai berikut:

$f_{i}\left(t_{i j}\right)=\sum_{s=1}^{p} \beta_{i s q} x_{i j q}^{s}+\sum_{s=1}^{m} \beta_{i[s+p] q}\left(t_{i j q}-k_{i s q}\right)_{+}^{p}, i=1,2, \ldots$

dengan $\beta_{i 1 q}, \beta_{i 2 q}, \mathrm{~K}, \beta_{i[p+m] q}$ adalah parameter fungsi spline pada subjek ke- $i$ dan variabel prediktor ke- $q$,

$$
\left(x_{i j q}-k_{i s q}\right)_{+}^{p}=\left\{\begin{array}{cl}
\left(x_{i j q}-k_{i s q}\right)^{p} & ,\left(x_{i j q}-k_{i s q}\right) \geq 0 \\
0 & ,\left(x_{i j q}-k_{i s q}\right)<0
\end{array}\right. \text {. }
$$

Selanjutnya fungsi spline polynomial truncated biprediktor pada pers. (2) dapat ditulis menjadi:

$$
f=\mathbf{X} \beta \text {, }
$$

dan model regresi spline polynomial truncated biprediktor dapat dituliskan sebagai berikut:

$$
\underset{\sim}{y}=\mathbf{X} \beta+\varepsilon
$$

dengan $\underset{\sim}{y}=\left(\underset{\sim}{y_{1}}, \underset{\sim}{y_{2}}, \ldots{ }_{\sim}^{\backslash T}\right.$ adalah vektor variabel respon, $\underset{\sim}{\beta}=\left(\underset{\sim}{\beta}, \underset{\sim}{\beta}, \ldots{ }_{\sim}\right.$ adalah vektor parameter yang tidak diketahui, dan $\mathbf{X}$ adalah matriks yang tergantung pada titik knots yaitu:

24 Anna Islamiyati, "Estimator Penalized Spline Pada Model Regresi Nonparametrik Multirespon Multiprediktor Untuk Data Longitudinal” (postdoctoral, Universitas Airlangga, 2019), http://lib.unair.ac.id. 


$$
\begin{aligned}
& \mathbf{X}=\left[\begin{array}{cccccccccc}
\underset{\sim}{x} & \underset{\sim}{x} x^{2} & \cdots & \sim & \sim & \sim & \cdots & & & \\
\underset{\sim}{x} & \underset{\sim}{x} & \ldots & \sim & \sim & \sim & \cdots & \sim & \sim & \\
\vdots & \vdots & \ddots & \vdots & & \vdots & \ddots & & \vdots & \\
\underset{\sim}{x} & \underset{\sim}{x} & \cdots & & & & \cdots & & & 1
\end{array}\right.
\end{aligned}
$$

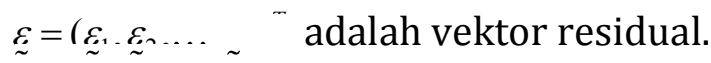

Selanjutnya melalui pendekatan least square dengan meminimumkan error pada pers. (3), diperoleh taksiran parameter $\hat{\beta}$ adalah:

$$
\hat{\beta}=\left(\mathbf{X}^{T} \mathbf{X}\right)^{-1} \mathbf{X}^{T} \underset{\sim}{y}
$$

sehingga diperoleh estimasi fungsi spline polynomial truncated biprediktor adalah:

$$
\hat{f}_{i}\left(t_{i j}\right)=\sum_{s=1}^{p} \hat{\beta}_{i s q} x_{i j q}^{s}+\sum_{s=1}^{m} \hat{\beta}_{i[s+p] q}\left(t_{i j q}-k_{i s q}\right)_{+}^{p}
$$

Berdasarkan pers (4), taksiran model regresi spline polynomial truncated biprediktor adalah:

$$
\hat{y}_{i j}=\hat{f}_{i}\left(t_{i j}\right)
$$

atau dapat ditulis menjadi:

$$
\hat{y}_{i j}=\sum_{s=1}^{p} \hat{\beta}_{i s q} x_{i j q}^{s}+\sum_{s=1}^{m} \hat{\beta}_{i[s+p] q}\left(x_{i j q}-k_{i s q}\right)_{+}^{p}, \text { untuk } q=1,2 .
$$

\section{Identifikasi Pola Trombosit Pasien DBD}

Jumlah trombosit pada pasien DBD yang dirawat di rumah sakit, menunjukkan kondisi yang berbeda-beda pada setiap pasien. Hal yang menakutkan pada penyakit DBD adalah terdapat siklus saat pasien tidak menyadari penyakitnya, dan berujung kematian. Oleh sebab itu, identifikasi pola trombosit pasien DBD melalui analisis data longitudinal menjadi penting untuk dilakukan, supaya kondisi pasien pada setiap hari perawatan dapat dimodelkan sebagai salah satu referensi dalam penanganan penyakit DBD. Kandungan trombosit dan hemoglobin pasien DBD yang bervariasi ditunjukkan pada Tabel 1 .

Tabel 1 menunjukkan bahwa sebagian besar pasien terindikasi penyakit DBD karena memiliki jumlah trombosit di bawah normal, begitupun dengan jumlah hematokrit pasien juga tidak normal. Terdapat 1 pasien yang memiliki jumlah trombosit normal, tetapi memiliki hematokrit yang tidak normal. Juga terdapat 1 pasien yang memiliki trombosit tidak normal namun hematokritnya normal. Hal ini menunjukkan bahwa indikasi seseorang menderita DBD tidak harus jumlah trombosit dan hematokrit yang tidak normal, namun dapat pula hanya trombosit yang tidak normal atau hanya hematokrit yang tidak normal. Meskipun dari data terlihat bahwa sebagian 
besar pasien diindikasikan menderita DBD karena trombosit yang rendah dan hematokrit yang tinggi.

Tabel 1 Deskripsi pasien DBD sebelum di rawat

\begin{tabular}{|c|c|c|c|}
\hline Pasien & $\begin{array}{c}\text { Trombosit/Tr } \\
\left(150-400 / \mathrm{mm}^{3}\right)\end{array}$ & $\begin{array}{l}\text { Hematokrit/Ht } \\
(33-38 \%)\end{array}$ & Keterangan \\
\hline 1 & 72 & 53,2 & Tr dan Ht tidak normal \\
\hline 2 & 132 & 52,7 & Tr dan Ht tidak normal \\
\hline 3 & 267 & 53,8 & $\begin{array}{l}\text { Tr normal dan Ht tidak } \\
\text { normal }\end{array}$ \\
\hline 4 & 145 & 55,7 & Tr dan Ht tidak normal \\
\hline 5 & 28 & 53,2 & Tr dan Ht tidak normal \\
\hline 6 & 180 & 52,9 & Tr dan Ht tidak normal \\
\hline 7 & 82 & 38,0 & $\begin{array}{l}\text { Tr tidak normal dan } \mathrm{Ht} \\
\text { normal }\end{array}$ \\
\hline 8 & 103 & 47,3 & Tr dan Ht tidak normal \\
\hline 9 & 132 & 56,9 & Tr dan Ht tidak normal \\
\hline 10 & 145 & 56,1 & Tr dan Ht tidak normal \\
\hline
\end{tabular}

Kecenderungan perubahan trombosit pada setiap waktu perawatan relatif bervariasi sehingga mengikuti pola nonparametrik. Spline yang optimal ditentukan dengan pemilihan titik knot optimal melalui nilai GCV terkecil. Prosedur analisis model dilakukan melalui pemilihan titik knot 1 dengan orde 1 untuk semua pasien. Selanjutnya diperoleh model parsial yang optimal dari masing-masing pasien seperti Gambar 1. Terdapat 10 pola perubahan jumlah trombosit selama 11 hari perawatan di rumah sakit. Selengkapnya pola perubahan trombosit pasien ditunjukkan Tabel 2.

Berdasarkan Gambar 1 dan Tabel 2 menunjukkan bahwa kondisi perubahan jumlah trombosit pasien DBD selama menjalani perawatan di rumah sakit terlihat bervariasi. Jika dikelompokkan variasi perubahan pola trombosit tersebut, maka dapat diperoleh 4 pola perubahan trombosit, yaitu (1) trombosit turun hingga hari ke-2, dan selanjutnya meningkat hingga keluar dari rumah sakit, (2) trombosit turun terus hingga hari ke-3, baru selanjutnya mengalami peningkatan hingga keluar dari rumah sakit, (3) trombosit agak lama mengalami penurunan, yaitu hingga hari ke-6 perawatan, setelah itu mulai ada peningkatan hingga hari terakhir perawatan, dan (4) jumlah trombosit pasien DBD tidak pernah mengalami penurunan, tetapi terus mengalami peningkatan, meskipun di awal-awal perawatan peningkatannya tidak setajam di akhir-akhir perawatan. 
Tabel 2 Pola perubahan jumlah trombosit pasien DBD berdasarkan waktu perawatan

\begin{tabular}{|c|c|}
\hline Pasien & $\begin{array}{l}\text { Pola perubahan jumlah trombosit }(y) \\
\text { pada setiap hari perawatan }(t)\end{array}$ \\
\hline 1 & $\begin{array}{l}\text { Trombosit mengalami peningkatan setelah } 1 \text { hari perawatan, dan } \\
\text { terus meningkat hingga hari terakhir perawatan pasien. }\end{array}$ \\
\hline 2 & $\begin{array}{l}\text { Sebelum perawatan hingga hari ke-2 di rumah sakit, terlihat } \\
\text { trombosit menurun drastis, namun setelah itu meningkat tajam. }\end{array}$ \\
\hline 3 & $\begin{array}{l}\text { Hingga hari ke-3, trombosit sangat menurun tajam, namun } \\
\text { meningkat setelah hari ketiga hingga terakhir perawatan. }\end{array}$ \\
\hline 4 & $\begin{array}{l}\text { Trombosit turun mulai dari awal pemeriksaan hingga hari ke-2, } \\
\text { dan selanjutnya meningkat terus. }\end{array}$ \\
\hline 5 & $\begin{array}{l}\text { Kondisi trombosit pasien dari awal pemeriksaan hingga dirawat } \\
\text { sampai keluar dari rumah sakit terlihat meningkat terus, hanya } \\
\text { pada hari ke-0 hingga hari ke- } 7 \text { terlihat peningkatan tidak setajam } \\
\text { setelah hari-hari terakhir perawatan. }\end{array}$ \\
\hline 6 & $\begin{array}{l}\text { Trombosit turun hingga hari ke-3 perawatan, setelah itu mulai } \\
\text { meningkat hingga hari terakhir perawatan. }\end{array}$ \\
\hline 7 & $\begin{array}{l}\text { Trombosit sangat lama mengalami penurunan, terlihat hingga hari } \\
\text { ke-6 perawatan, trombosit terus turun, hari ke-7 hingga hari } \\
\text { terakhir perawatan baru mengalami peningkatan jumlah } \\
\text { trombosit pasien. }\end{array}$ \\
\hline 8 & $\begin{array}{l}\text { Penurunan trombosit terjadi hingga hari ke-2, setelah itu mulai } \\
\text { mengalami peningkatan sangat tajam. }\end{array}$ \\
\hline 9 & $\begin{array}{l}\text { Penurunan trombosit turun hingga hari ke-3, kemudian meningkat } \\
\text { terus hingga keluar dari rumah sakit. }\end{array}$ \\
\hline 10 & Penurunan trombosit turun hingga hari ke-2, kemudian perlahan \\
\hline
\end{tabular}

Selanjutnya untuk kandungan hematokrit pasien rata-rata di atas normal berdasarkan indikasi DBD untuk jumlah hematokrit mengalami peningkatan sama dengan atau di atas 20\%. Namun, terlihat pada data, bahwa rata-rata pasien memiliki hematokrit di awal pemeriksaan belum meningkat sebesar 20\% namun terindikasi DBD. Hal ini menunjukkan bahwa sangat penting untuk melihat keterkaitan antara hematokrit dan trombosit pada kondisi-kondisi tertentu. Titik knot ditentukan pada nilai hematokrit sebesar 38\%, hal ini dimaksudkan untuk melihat perubahan trombosit ketika nilai hematokrit tidak normal, yaitu di atas 38\%. Selengkapnya dapat dilihat pada Tabel 3 dan Gambar 2. 

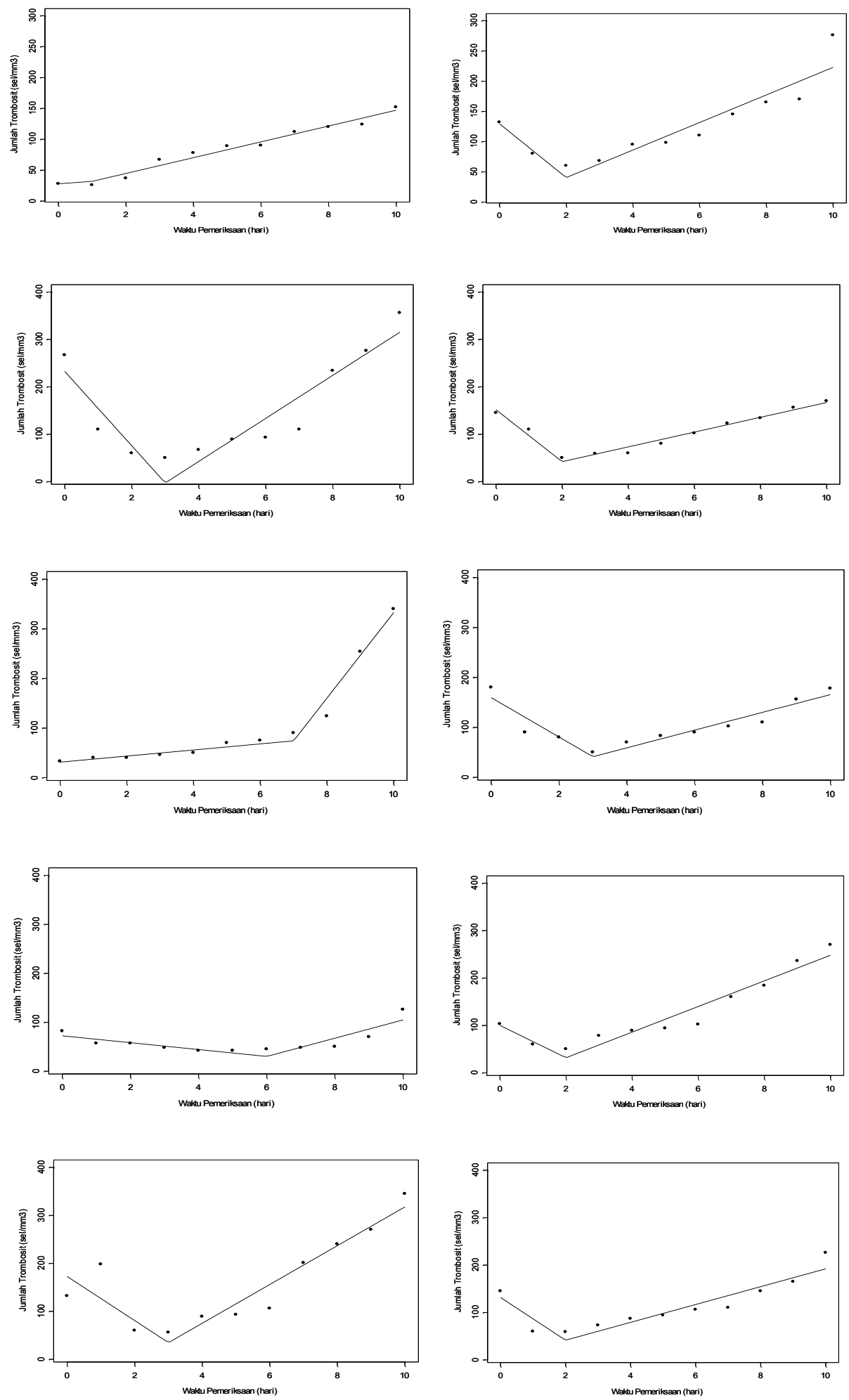

Gambar 1 Kurva hubungan jumlah trombosit (y) dengan waktu perawatan $(t)$, dengan fungsi spline polynomial truncated biprediktor 

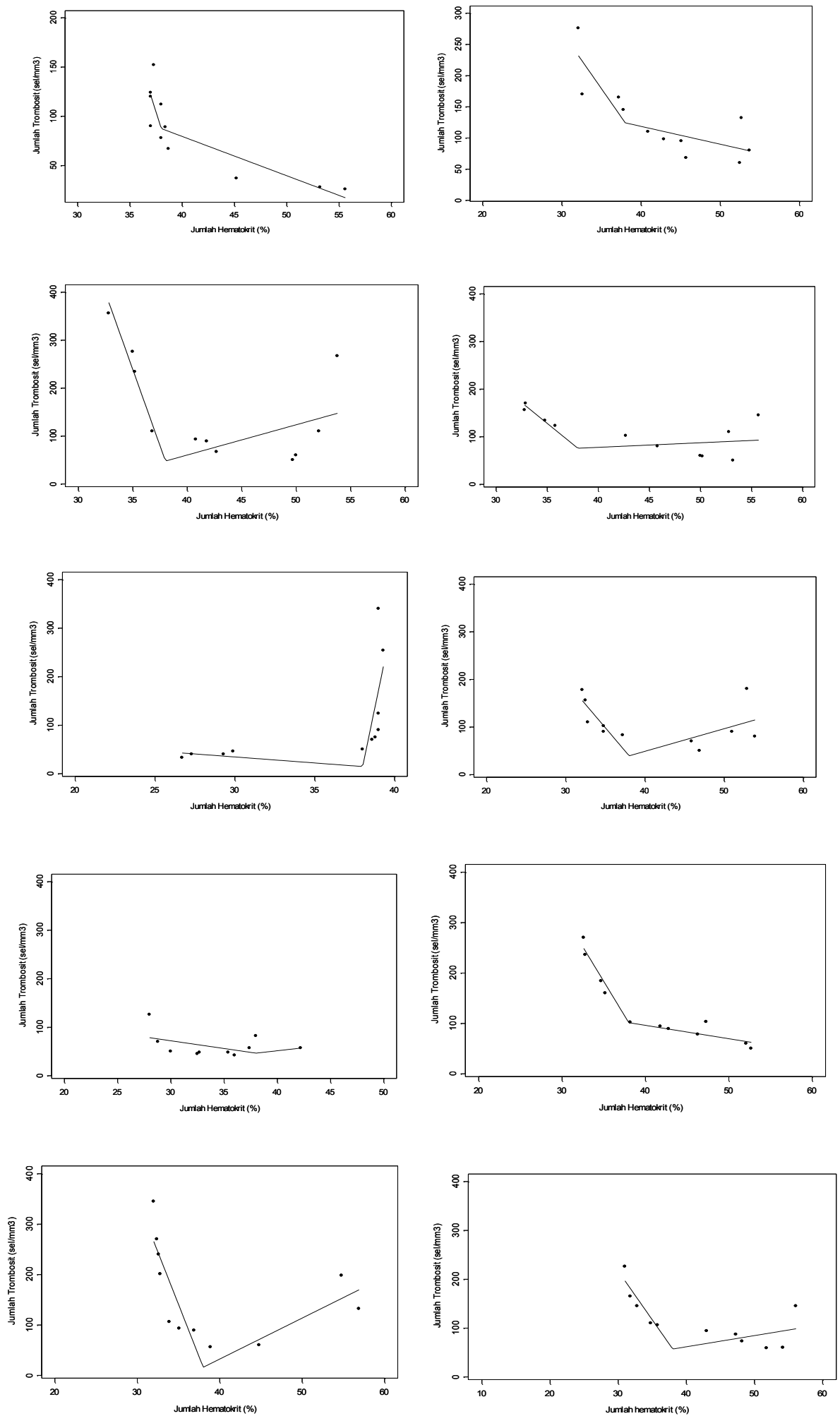

Gambar 2. Kurva hubungan jumlah trombosit $(y)$ dengan hematokrit $\left(x_{2}\right)$, dengan fungsi spline polynomial truncated biprediktor 
Tabel 3 Pola perubahan jumlah trombosit pasien DBD berdasarkan jumlah hematokrit pasien

\begin{tabular}{|c|c|}
\hline Pasien & $\begin{array}{l}\text { Pola perubahan jumlah trombosit }(y) \\
\text { berdasarkan jumlah hematokrit }\left(\mathrm{x}_{2}\right)\end{array}$ \\
\hline 1 & $\begin{array}{l}\text { Terlihat hubungan negatif antara trombosit dengan hematokrit } \\
\text { hingga batas normal } 38 \% \text {. Terlihat setelah hematokrit melebihi } \\
38 \% \text {, jumlah trombosit menurun secara tajam. }\end{array}$ \\
\hline 2 & $\begin{array}{l}\text { Semakin tinggi hematokrit semakin rendah jumlah trombosit } \\
\text { pasien, dan ketika hematokrit melebihi } 38 \% \text {, jumlah trombosit } \\
\text { menurun. }\end{array}$ \\
\hline 3 & $\begin{array}{l}\text { Pada pasien ini, terlihat penurunan trombosit yang sangat tajam } \\
\text { pada kisaran normal hematokrit, tapi ketika hematokrit } \\
\text { melebihi } 38 \% \text { justru terlihat trombosit mengalami peningkatan } \\
\text { meskipun jumlah trombositnya tidak dalam batas normal. }\end{array}$ \\
\hline 4 & $\begin{array}{l}\text { Trombosit menurun seiring dengan meningkatnya hematokrit } \\
\text { menuju tidak normal, dan setelah melebihi } 38 \% \text { terlihat } \\
\text { perubahan trombosit sangat kecil. }\end{array}$ \\
\hline 5 & $\begin{array}{l}\text { Terlihat jumlah trombosit menurun seiring dengan penambahan } \\
\text { jumlah hematokrit pasien, namun mengalami peningkatan } \\
\text { trombosit pada saat hematokrit tinggi. }\end{array}$ \\
\hline 6 & $\begin{array}{l}\text { Trombosit turun seiring penambahan hematokrit hingga } \\
\text { mencapai } 38 \% \text {, namun terlihat meningkat ketika hematokrit } \\
\text { melebihi } 38 \% \text {. }\end{array}$ \\
\hline 7 & $\begin{array}{l}\text { Trombosit turun perlahan ketika hematokrit bertambah hingga } \\
38 \% \text {, setelah itu trombosit mengalami sedikit peningkatan. }\end{array}$ \\
\hline 8 & $\begin{array}{l}\text { Trombosit sangat turun tajam ketika hematokrit bertambah } \\
\text { hingga 38\% dan terus mengalami penurunan ketika hematokrit } \\
\text { tinggi. }\end{array}$ \\
\hline 9 & $\begin{array}{l}\text { Trombosit turun drastis ketika mencapai 38\%, namun terlihat } \\
\text { trombosit pasien setelah meningkat dari 38\%. }\end{array}$ \\
\hline 10 & $\begin{array}{l}\text { Trombosit turun hingga hematokrit mencapai } 38 \% \text {, dan } \\
\text { mengalami peningkatan yang tidak tajam pada jumlah trombosit } \\
\text { ketika hematokrit tidak normal atau meningkat dari } 38 \% \text {. }\end{array}$ \\
\hline
\end{tabular}

Taksiran model regresi nonparametrik spline untuk jumlah trombosit pasien DBD berdasarkan waktu perawatan dan jumlah hemtokrit diperoleh sebagai berikut: 


$$
\begin{aligned}
\hat{y}_{i j}= & 3,93 t_{1}+8,87\left(t_{1}-1\right)_{+}-33,54 x_{1}+29,55\left(x_{1}-38\right)_{+}-44,51 t_{2}+67,29\left(t_{2}-2\right)_{+}+ \\
& -18,22 x_{2}+15,36\left(x_{2}-38\right)_{+}-78,38 t_{3}+123,79\left(t_{3}-3\right)_{+}-63,59 x_{3}+69,90\left(x_{3}-38\right)_{+}+ \\
& -54,72 t_{4}+70,32\left(t_{4}-2\right)_{+}-17,42 x_{4}+18,39\left(x_{4}-38\right)_{+}+6,13 t_{5}+80,05\left(t_{5}-7\right)_{+}+ \\
& -2,47 x_{5}+161,02\left(x_{5}-38\right)_{+}-39,42 t_{6}+57,19\left(t_{6}-3\right)_{+}-19,62 x_{6}+24,36\left(x_{6}-38\right)_{+}+ \\
& -7,02 t_{7}+25,66\left(t_{7}-6\right)_{+}-3,189 x_{7}+5,67\left(x_{7}-38\right)_{+}-34,07 t_{8}+61,11\left(t_{8}-38\right)_{+}+ \\
& -27,29 x_{8}+24,64\left(x_{8}-38\right)_{+}-45,94 t_{9}+86,35\left(t_{9}-3\right)_{+}-41,58 x_{9}+49,71\left(x_{9}-38\right)_{+}+ \\
& -45,06 t_{10}+63,88\left(t_{10}-2\right)_{+}-19,93 x_{10}+22,22\left(x_{10}-38\right)_{+}
\end{aligned}
$$

Hasil taksiran model regresi diperoleh nilai $\mathrm{R}^{2}=95,5 \%$ dengan GCV $=$ 714,72 , artinya model sudah layak digunakan untuk mengidentifikasi pola perubahan trombosit berdasarkan pengaruh dari waktu perawatan dan jumlah hematokrit. Pola trombosit pasien yang berbeda-beda menunjukkan bahwa perubahan jumlah trombosit pada setiap pasien DBD adalah bervariasi pada setiap pasien, sehingga perlu penanganan yang berbeda pula selama perawatan. Misalnya, terdapat pasien yang memiliki jumlah trombosit naik setelah perawatan hari ke-7, ada pula yang sudah mulai meningkat hanya satu hari perawatan.

Selanjutnya, pola perubahan trombosit berdasarkan jumlah hematokrit, menunjukkan bahwa rata-rata trombosit menurun seiring meningkatnya hematokrit sampai pada batas normal hematokrit yaitu 38\%. Namun ketika hematokrit semakin tinggi, di atas 38\%, terlihat pola yang berbeda pada pasien. Yaitu terdapat pasien yang trombositnya terus turun, dan ada pula pasien yang memiliki trombosit justru meningkat. Hasil ini tentunya menjadi informasi bagi tim medis untuk mempersiapkan tindakan penanganan pada setiap pasien DBD yang berbeda-beda, karena kecenderungan kenaikan trombosit pada pasien berbeda-beda.

\section{Kesimpulan}

Hasil estimator spline polynomial truncated biprediktor layak digunakan pada data pasien DBD karena diperoleh nilai koefisien determinasi $\mathrm{R}^{2}$ 95,5\%. Terdapat empat pola perubahan peningkatan jumlah trombosit pasien dari keseluruhan pasien yang dianalisis berdasarkan waktu perawatan, dan tiga pola perubahan berdasarkan hematokrit. Pola perubahan jumlah trombosit berdasarkan hematokrit menunjukkan bahwa rata-rata perubahan trombosit mengalami penurunan ketika hematokrit mencapai batas normal yaitu 38\%. Ketika hematokrit di atas 38\%, maka terdapat pasien yang memiliki jumlah trombosit terus turun, dan ada pula trombosit yang mengalami peningkatan.

Pada penelitian selanjutnya, perlu untuk melihat perubahan trombosit berdasarkan fase DBD melalui pendekatan kuantil dan estimator lain dalam 
regresi nonparametrik, misalnya estimator penalized spline. Keterlibatan fungsi penalti dalam penalized spline diharapkan mampu memberikan hasil estimasi yang smooth.

\section{Daftar Pustaka}

Anna Islamiyati. "Estimator Penalized Spline Pada Model Regresi Nonparametrik Multirespon Multiprediktor Untuk Data Longitudinal." Postdoctoral, Universitas Airlangga, 2019. http://lib.unair.ac.id.

Aydın, Dursun, Memmedağa Memmedli, and Rabia Ece Omay. "Smoothing Parameter Selection for Nonparametric Regression Using Smoothing Spline | Aydin | European Journal of Pure and Applied Mathematics." $\begin{array}{lll}\text { Accessed December } & 2019 .\end{array}$ https://www.ejpam.com/index.php/ejpam/article/view/1362.

Budiantara, I. Nyoman, Madu Ratna, Ismaini Zain, and Wahyu Wibowo. "Modeling the Percentage of Poor People in Indonesia Using Spline Nonparametric Regression Approach." International Journal of Basic \& Applied Sciences 12 (2012): 119-124.

Budiantara, I. Nyoman, Vita Ratnasari, Madu Ratna, and Ismaini Zain. "The Combination of Spline and Kernel Estimator for Nonparametric Regression and Its Properties." Applied Mathematical Sciences 9, no. 122 (2015): 6083-6094.

Chamidah, N., I. N. Budiantara, S. Sunaryo, and I. Zain. "Designing of Child Growth Chart Based on Multi-Response Local Polynomial Modeling." Journal of Mathematics and Statistics 8, no. 3 (2012): 342-347.

Chamidah, N., and M. Rifada. "Local Linear Estimator in Bi-Response Semiparametric Regression Model for Estimating Median Growth Charts of Children." Far East Journal of Mathematical Sciences 99, no. 8 (2016): 1233.

Chamidah, Nur, and Budi Lestari. "Spline Estimator in Homoscedastic Multiresponse Nonparametric Regression Model in Case of Unbalanced Number of Observations." Far East Journal of Mathematical Sciences (FJMS) $\quad 100 \quad$ (November 3, 2016): 1433-53. https://doi.org/10.17654/MS100091433.

Charisma, Acivrida Mega. "Gambaran Hasil Pemeriksaan Jumlah Trombosit Dan Nilai Hematokrit Pada Pasien Demam Berdarah Dengue (DBD) Di RSU Anwar Medika Periode Februari-Desember 2016." Journal of Pharmacy and Science 2, no. 2 (July 7, 2017): 15-19.

Grajeda, Laura M., Andrada Ivanescu, Mayuko Saito, Ciprian Crainiceanu, Devan Jaganath, Robert H. Gilman, Jean E. Crabtree, et al. "Modelling Subject-Specific Childhood Growth Using Linear Mixed-Effect Models with Cubic Regression Splines." Emerging Themes in Epidemiology 13 (January 7, 2016). https://doi.org/10.1186/s12982-015-0038-3.

Islamiyati, A., Fatmawati, and N. Chamidah. "Estimation of Covariance Matrix on Bi-Response Longitudinal Data Analysis with Penalized Spline Regression." Journal of Physics: Conference Series 979 (March 2018): 012093. https://doi.org/10.1088/1742-6596/979/1/012093. 
Islamiyati, Anna. "Spline Polynomial Truncated Dalam Regresi Nonparametrik." Jurnal Matematika, Statistika Dan Komputasi 14, no. 1 (February 11, 2018): 54-60. https://doi.org/10.20956/jmsk.v14i1.3538.

-_-. "Taksiran Kurva Regresi Spline Pada Data Longitudinal Dengan Kuadrat Terkecil." Jurnal Matematika, Statistika Dan Komputasi 11, no. 1 (February 1, 2018): 77-83. https://doi.org/10.20956/jmsk.v11i1.3432.

Islamiyati, Anna, Fatmawati, and Nur Chamidah. "Ability of Covariance Matrix in Bi-Response Multi-Prredictor Penalized Spline Model Through Longitudinal Data Simulation." Preprint. INA-Rxiv, November 6, 2019. https://doi.org/10.31227/osf.io/bjqv4.

- - C. "Fungsi Goodness of Fit Dalam Kriteria Penalized Spline Pada Estimasi Regresi Nonparametrik Birespon Untuk Data Longitudinal." In Prosiding Seminar Nasional Matematika dan Aplikasinya 2017: Peranan Matematika dan Sistem Informasi di Era Big Data untuk Menunjang Perkembangan Iptek di Indonesia, 216-21. Surabaya: Departemen Matematika Fakultas Sains dan Teknologi Universitas Airlangga Surabaya, 2017.2 http://math.fst.unair.ac.id/wpcontent/uploads/2017/10/32-Anna-Islamiyati_Statistika_pdf.

Kementerian Kesehatan Republik Indonesia. "Demam Berdarah Biasanya Mulai Meningkat Di Januari,” January 8, 2015. http://www.depkes.go.id/ article/print/15011700003.

Lestari, B., Fatmawati, I. N. Budiantara, and N. Chamidah. "Estimation of Regression Function in Multi-Response Nonparametric Regression Model Using Smoothing Spline and Kernel Estimators." Journal of Physics: Conference Series 1097 (September 2018): 012091. https://doi.org/10.1088/1742-6596/1097/1/012091.

Liang, Hua, and Yuanhui Xiao. "Penalized Splines For Longitudinal Data With An Application In AIDS Studies." Journal of Modern Applied Statistical Methods 5, no. 1 (May 1, 2006). https://doi.org/10.22237/jmasm/1146456660.

Lontoh, Reinhard Y., A J M Rattu, and Wulan P. J. Kaunang. "Hubungan Antara Pengetahuan Dan Sikap Dengan Tindakan Pencegahan Demam Berdarah Dengue (DBD) Di Kelurahan Malalayang 2 Lingkungan III." Pharmacon 5, no. 1 (February 9, 2016). https://ejournal.unsrat.ac.id/index.php/pharmacon/article/view/1138 2.

Nisai, Shofa F., and I. Nyoman Budiantara. "Analisis Survival dengan Pendekatan Multivariate Adaptive Regression Splines pada Kasus Demam Berdarah Dengue (DBD)." Jurnal Sains dan Seni ITS 1, no. 1 (September 11, 2012): D318-D323-D323. https://doi.org/10.12962/j23373520.v1i1.2165.

Seera, Manjeevan, Chee Peng Lim, Shing Chiang Tan, and Chu Kiong Loo. "A Hybrid FAM-CART Model and Its Application to Medical Data Classification." Neural Computing and Applications 26, no. 8 (November 1, 2015): 1799-1811. https://doi.org/10.1007/s00521-015-1852-9. 
Sriliana, Idhia, and Nyoman Budiantara. "Truncated Spline Regression in Linear Partial Model for Longitudinal Data," 2012.

Sudiarsa, I. Wayan, I. Nyoman Budiantara, Suhartono, and Santi Wulan Purnami. "Combined Estimator Fourier Series and Spline Truncated in Multivariable Nonparametric Regression." Applied Mathematical Sciences
https://doi.org/10.12988/ams.2015.55394. 4997-5010. 